\title{
The Framework for Fundamental Rights Protection in Europe under the Prospect of EU Accession to ECHR
}

\author{
Konstantinos Margaritis ${ }^{1}$ \\ ${ }^{1}$ LLM, International and European Public Law, Attorney at Law, Heraklion Bar Association, Greece \\ Correspondence: Konstantinos Margaritis, 50, Chrisostomou Avenue, 71306 Heraklion Crete, Greece. Tel: \\ 30-694-599-9593. E-mail: konstantinos_margaritis@yahoo.com
}

Received: October 17, 2012 Accepted: December 3, 2012 Online Published: February 26, 2013

doi:10.5539/jpl.v6n1p64

URL: http://dx.doi.org/10.5539/jpl.v6n1p64

\begin{abstract}
Issues of human rights have always been crucial in the continent of Europe. The institutionalization of fundamental rights for European citizens remained a matter of much discussion among legal scholars for decades. With the amendment of the Lisbon Treaty, major changes were forwarded within the Union regarding that matter; one of those is the accession of the Union to ECHR. The purpose of this paper is to discuss major institutional aspects of this accession and propose solutions, after addressing certain difficulties on one hand and on the other, to draw the new picture of judicial protection of fundamental rights in Europe.
\end{abstract}

Keywords: human rights in Europe, EU accession to ECHR, judicial protection in Europe

\section{Introduction}

A possible accession of European Union (hereinafter: EU/the Union) to the European Convention on Human Rights (ECHR/the Convention) has been discussed in legal society for more than thirty years. The topic had widely opened after the 1979 Commission Memorandum where the major pros and cons were underlined and practical problems were addressed. This discussion led to an official request to the European Court of Justice (ECJ/the Court) in relation to the legality of such accession; the outcome was included in opinion 2/94 that found such accession incompatible with the European Community (EC/the Community) Treaty.

However, the whole argumentation regarding EU accession to ECHR had originated earlier, the first approach of the sensitive issue of fundamental rights protection at an EU level was directed by the ECJ that had envisaged the conceptual influence of the Convention to the EU and developed the doctrine of Community protection of fundamental rights.

Technical problems arose from the other part as well. The ECHR was constructed for States to participate in so the accession of an organization such as the EU would demand significant amendments. A relevant proposal from the Council of Europe's point of view was manifested in the Steering Committee for Human Rights Study of 2002.

With the enforcement of the Lisbon Treaty and the signature and ratification of Protocol 14, technical problems seemed to have been put in some order. But this is the easy part of the story. The Union is an organisation with special characteristics and that creates interpretational issues regarding its accession to the Convention.

Furthermore, different perspectives derive from a possible accession of EU to the ECHR. As all EU member states will hold their present status as members of the Convention, the EU will unavoidably develop judicial relations with them as well as with non-EU members within the legal umbrella of the ECHR.

The aim of this paper is to understand and analyse the institutional changes that a possible accession to ECHR may bring to the system of fundamental rights protection in EU. This will be achieved by trying to identify the position of the ECHR in the EU legal order and later to define the formation of the relations among the ECHR Member States and EU in view of the accession of the latter in the Convention from a judicial standpoint.

\section{Legal Basis}

\subsection{The New Article 6, par. 2, Section 1 TEU and Further Process}

Under the precise rule of the Court in opinion 2/94 it needed a Treaty amendment for the Community (of the time) to accede to the ECHR as an outcome of the absence of an explicit competence. This amendment was forwarded and a specific provision was entered in the Treaty establishing the Constitution for Europe, a Treaty that was never 
enacted. However, the matter of accession was not removed from the EU agenda and subsequently was included in the Treaty of Lisbon which finally came into force on 1st of December 2009. According to the new article 6, par. 2, section 1 TEU: "the Union shall accede to the European Convention for the Protection of Human Rights and Fundamental Freedoms".

The way that this provision is formulated describes the Union's accession not simply as a wish or a general idea, but more as a duty. In general terms, provisions are technically enounced in either an obligatory or a more permissive mode within the EU legal system; this is usually expressed with the terms "shall" and "may" respectively. The term "shall" exactly reflects the sense of obligation within a future time instead of the term "may" that gives more freedom in acting (Tillman, 2010). Article 8 TEU could be an example for both categories; par. 1 dictates that the Union shall develop good relations with neighboring countries, whilst par. 2 states that the Union may conclude specific agreements with those countries. Hence, the terminology used in article 6, par. 2, section 2 underlines the importance on this issue.

The above mentioned provision should not be examined independently of article $2 \mathrm{TEU}$. This article, outcome of the Lisbon amendment as well, illustrates the democratic qualities and values of the Union that form part of the common EU identity and inserts a general background for the protection of fundamental rights within the Union to be based on and therefore materialized. This basis has an explicit presence within the autonomous EU legal order and all the more in the forefront of the Treaty and takes a symbolic approach in providing the Union with the obligation to accede to ECHR (Piris, 2010).

A major matter that the Lisbon Treaty establishes is the legal personality of the Union, in article 47 TEU. From the enactment of the Treaty of Rome, the Member States intended to attribute legal personality to the Community to act in international scene by concluding international agreements (Frid, 1995; Leal-Arcas, 2006) under the principle of conferred powers. The situation became far more complex after the creation of the European Union, a new entity that was based in the three pillar system. The two new pillars (Common Foreign and Security Policy, Justice and Home Affairs) that were introduced in the Maastricht Treaty, along with the existing European Community, substantially changed the institutional framework around the Community (McGoldrick, 1997). Therefore an issue arose regarding the legal personality of the Union itself, an open issue until the Lisbon Treaty era. Under the Lisbon framework the three pillar system is abolished (Craig, 2008) and is replaced with a merged legal personality for the Union which leads to the ability of the latter to participate in international agreements.

For the completion of the accession, an international agreement in the form of an accession treaty need to be concluded according to the parameters set in article 218 TFEU. Under the new architecture of the Union's external relations action, this provision entails all procedural matters for negotiating and concluding an international agreement. As seen throughout article 218 TFEU, mainly the Council determines the organization of the Union's negotiation process, while receiving recommendations from the Commission or the High Representative of the Union for Foreign Affairs and Security Policy regarding topics of the ex-second pillar (par. 3) and is finally responsible for concluding the agreement (par. 6). In the case of EU accession, the consent of the European Parliament is required for the conclusion of the agreement (par. 6, section a, issue ii), while the Council's final decision on concluding the EU accession agreement shall be taken unanimously and ratified by the member states in conformance with their constitutional requirements (par. 8).

An issue that may raise problems regarding the conclusion of an agreement for EU accession to ECHR is deriving from article 218, par. 11 TFEU. According to that provision, any of the formal EU institutions involved in the process (Council, Commission, European Parliament) as well as every member state may seek an opinion from the ECJ as to whether the agreement is compatible with the Treaties. The term "compatibility" refers to both the procedural provisions of the Treaties (i.e. article 218 TFEU) and provisions of substantial nature (ECJ Opinion 2/00; De Baere, 2008). Both situations do not really affect a possible accession since the reasons that made the accession incompatible with the Treaties have been already expressed (ECJ Opinion 2/94) and surpassed through the Lisbon amendment. What may affect the conclusion of an accession agreement regarding "compatibility" is whether it may also include review of specific clauses of the agreement between the EU and the ECHR as the agreement will still be "envisaged" under the concept of article 218 TFEU (ECJ Opinion 1/75; Arnull, 1999; Eeckhout, 2004). In a positive response, re-negotiations will become necessary if the Court finds asymmetries between clauses of the drafted agreement and the Treaties; this process may end to be highly time consuming especially if the initial negotiations have reached final stages.

From a more practical approach the European Commission and the Council of Europe started official negotiations on the $7^{\text {th }}$ of July 2010 with Viviane Reding, Vice-President of the Commission and Thorbjørn Jagland, Secretary General of the Council of Europe representing the two bodies (Council of Europe, 2010a). The elaboration of a 
legal instrument, or instruments, setting out the modalities of accession of the European Union to the European Convention on Human Rights, including its participation in the Convention system and the examination of any related issue shall be achieved at the latest by 30 June 2011 according to a recent CDDH report (Steering Committee for Human Rights, 2010). The result of an "informal" working group has been presented in a draft agreement (Steering Committee for Human Rights, 2011).

\subsection{Further ECHR Amendments and Process of Accession}

From the Council of Europe's point of view, Protocol 14 had been already formulated since 2004. The most important amendment regarding the EU accession to the Convention is that of article 59 ECHR. According to article 17 of the Protocol 14, a new paragraph shall be inserted that provides the Union with the opportunity to accede. This new paragraph of article 59 states that: "the European Union may accede to this Convention". The intention regularly expressed by the Council of Europe in welcoming the EU to the ECHR is regulated therein. Protocol 14 technically initiated, from the ECHR law perspective, the changes within the Convention for a possible EU accession, but still further modifications shall be agreed for the continuation of the accession process (Council of Europe, 2010b).

A clarification shall be made with reference to the terms that demonstrate the State-oriented direction of the Convention. The solution proposed by the Commission in the 1979 Memorandum that was later confirmed by the Steering Committee in its 2002 Report, of inserting an interpretative clause regarding the application of those terms to the Union in the accession treaty seems adequate to avoid any inconsistencies. Another more precise solution would be to insert a more general term; a probable one could be the "the High Contracting Parties" or simply "the signatories".

Far more important and complicated is the participation of the EU representatives in the Council of Europe's instruments that are in anyway related to the ECHR. The instrument directly set up within the ECHR is the ECtHR which ensures the observance of the engagements of the undertaken by the High Contracting Parties (article 19 ECHR). The appointment of a judge elected in respect of the EU complies perfectly with the ECHR provisions, thus no amendment is required therein. On the contrary, article 20 ECHR directs the number of judges as equal to the one of the High Contracting Parties and since the time of its accession, EU will be one.

Moreover, an EU judge may contribute to the development of better administration of justice in the ECtHR. The scope of EU activities becomes broader that it turns out to be difficult to distinguish any areas not affected by them (Davies, 2006). In that sense even more and more cases containing EU law may be brought before the ECtHR where the presence of a judge with expertise in EU law will be decisive. In fact, the Union had since many decades (ECJ Case C-26/62 Van Gend en Loos) constituted an autonomous legal order and developed its own legal system that included fundamental rights protection, especially with the inclusion of the EU Charter of Fundamental Rights in the new TEU. Hence, the EU judge will represent a legal system, different from that of the EU member states, for contributing to the legal multiculturalism of the ECtHR.

The process of selection of the EU judge will be one described in article 22 ECHR. For reasons of validity and democratic legitimacy, members of the EU Parliament shall participate in the electoral process in the Parliamentary Assembly, as the Union institutions will be responsible for nominating the three candidates as article 22 ECHR demands. The advisory opinion process of article 255 TFEU regarding the candidates for the ECJ may apply mutatis mutandis. Therefore, the EU judge in the ECtHR will enjoy more credibility being appreciated by legal specialists.

General, full participation of EU Parliamentarians in the Parliamentary Assembly of the Council of Europe would not be recommended for two main reasons. The first is related to the number of the members in the Assembly. Under the current standards, the Assembly consists of 642 members (321 principal and 321 substitutes) that represent the member states of the Council of Europe. As those seats are granted according to the population of each country, the disproportionately large EU population and the analogous seats would make the Assembly dysfunctional.

The other reason is related to political representation in the Assembly. The members of the Parliamentary Assembly are elected (appointed) among members of the National Parliaments. Delegations must show no worse a gender balance than the relevant national parliament, while the fair representation of political parties or groups within the Assembly shall be ensured (Evans and Silk, 2008). Therefore it could be observed that the Parliamentary Assembly signifies the political status quo of the member states of the Council of Europe. Although representatives are democratically elected every five years, the situation does not differ much in the European Parliament. Pan-European political parties have not developed a true "European" political identity but remain weak coalitions of the national parties and therefore dependent on them (Thomassen, 2002); a fact that leads to a 
deficit of democratic legitimacy in EU. European Parliamentarians simply follow policies as developed within their national political parties respectively. As a result, the only change that a possible participation of EU Parliamentarians could bring to the Parliamentary Assembly is simply to increase the number of representatives of EU member states in the Assembly. Nevertheless, co-operation between the two bodies could be enhanced by granting to EU the status of observer in the Assembly.

As regards the Committee of Ministers, an important reason that the participation of an EU representative in the Committee of Ministers could have been problematic is the absence of a common foreign policy related to human rights within the EU. Forasmuch as a task of the Committee of Ministers is to consult together international problems of common interest and try to take a common stand regarding events that violate the general ideas, on which the ECHR is based (de Vel, 1995), the EU could not have contributed much because of this lack of common policy. The issue of participation of the EU in the Committee of Ministers was also debased by the Commission which had proposed that the Committee should be excluded from proceedings relating to Community matters. Nevertheless, with the establishment of the High Representative of the Union for foreign affairs and security policy (HR), a different basis for developing a common foreign policy has been set (Verola, 2010). This does not automatically imply the acquisition of a political consensus in foreign affairs issues in the EU. However, the idea of a possible future participation of EU in the Committee of Ministers should not be abandoned.

With reference to the ECHR, the Committee of Ministers acts as a supervisor in the execution of the judgments of the ECtHR (article 46, par. 2, 3, 4 ECHR). The necessity of the Union to be able to participate in proceedings regarding the execution of the judgements is quite reasonable. High criticism has been voiced for the inconsistent approach of the Union in matters with reference to fundamental rights in particular within the Union itself (Turner, 1999; de Burca, 2002). And given the fact that twenty seven of the forty seven members of the Council of Europe are EU member states, a large amount of cases and hence violations, is subsequently brought against them. So the Union would be highly interested in participating in the process of supervision for the coherence of fundamental rights protection to be ensured, especially in its territory.

Plus, a potential supervision would increase the prestige of the Union as an organization that focuses on fundamental rights protection in practice. The gap between the actions of the Union and understanding by its citizens becomes a commonplace. As the Commission has pointed out (Commission of the European Communities, 2001), "they (the people) expect the Union to act as visibly as a national government". A step to achieve this visibility in fundamental rights issues could be participation in an organ that substantially guards compliance with fundamental rights, as the Committee of Ministers in the form of article 46 ECHR.

Fundamental changes need to be forwarded for complete EU accessions to ECHR were described above. What may be more important is the application of certain provision of the Convention to the special characteristics of the Union. Provisions like article 33 ECHR (inter-state cases), article 35, par. 2 (procedure of international investigation or settlement), the status of the Union when intervening or simply when being in a defending position and the possible judicial interaction with ECHR member states could create interpretational conflicts. An analysis of those matters will be attempted later in this paper.

\section{Re-structure of the "Pillars" of Fundamental Rights Protection in Europe}

Since the decade of the 50's two international organizations of extreme significance arose within the continent of Europe (de Lange, 2007). First the Council of Europe clearly focused on matters regarding the principles of rule of law and democracy with particular emphasis on human rights. The most important expression of those principles is the ECHR which 47 European countries have already accepted. Through the decades, more and more cases found their way to the ECtHR (Koopmans, 2003; Greer, 2008), a fact that demonstrates the magnitude of the achievement in the field of human rights. Alternatively, the EU, that started merely as an economic organization but consequently expanded its actions in many fields of policy, therefore, inevitably, the ECJ ruled upon cases including human rights.

This is probably the point where those two organizations of different structure finally meet. Protection of fundamental rights is essential, an issue of constitutional nature (Besselink, 2007) that is impossible to be excluded from the so-called European public order. Widely-accepted fundamental rights encompass mandatory rules that parties have no freedom to derogate from (Kessedjian, 2007). The sources of mandatory rules may (also) be sought in norms created at supra-national level, in the field of human rights the ECHR. In EU level, even before and besides the embracement in the Treaties, the Court has provided with many rulings that eventually accepted such rules of supra-national level within the EU legal order.

Furthermore, another form of interaction could be observed in the formulation of the criteria for accession to EU. According to article $49 \mathrm{TEU}$ any potential EU member state is obliged to respect the values that the EU is founded 
on and promote them. The relevant values of article 2 TEU represent the core of the Council of Europe whose aim is the greater unity of Europe through the common heritage of the countries that embodies their common thoughts and principles. It comes naturally that those common principles are connected with the rule of law, democracy and respect for human rights. Hence, the EU developed some standards for accepting new member states similar to the ideological background of the Council of Europe.

Therefore it would not be exaggerative to say that the interaction among the two supra-national legal orders (EU, Council of Europe) had already commenced as far as human rights are concerned. The interaction described will be upgraded in the future accession of EU to ECHR in the sense that the EU does not just accept the rules of the ECHR as guiding principles, but want to actively participate therein. So what remains is to examine to what extent this participation may occur.

The legal basis provided within the new TEU for accession to ECHR does not simply set an obligation for the Union; it also establishes the vertical effects of such an accession. Article 6, par. 2, section 2 TEU states: "such accession shall not affect the Union's competences as defined in the Treaties".

In further explaining the statement above, article 2 of Protocol 8 attached in Lisbon Treaty clarifies the retaining stability in the competences of all actors by dictating: "the agreement (for the accession to the ECHR) referred to in Article 1 shall ensure that accession of the Union shall not affect the competences of the Union or the powers of its institutions. It shall ensure that nothing therein affects the situation of Member States in relation to the European Convention, in particular in relation to the Protocols thereto, measures taken by Member States derogating from the European Convention in accordance with Article 15 thereof and reservations to the European Convention made by Member States in accordance with Article 57 thereof'.

This provision demands a multiple interpretation, both from the EU and from the member states point of view. Unlike the formulation of the relevant provision of article 6, par. 1 TEU regarding the recognition of the EU Charter of Fundamental Rights which states that the Charter shall not extend the competences of the Union, the word "affect" is used in both par. 2 and its explanatory article 2 of Protocol 8 . The reason seems to be quite simple; while in the formulation of the EU Charter, the actors involved in the field of human rights protection are the Union with its member states. As EU primary law, the Charter is binding to all EU member states under the principle of supremacy. Nevertheless as it is explicitly mentioned in article 53, the Charter shall not restrict human rights as are recognized by the Constitutions of the member states. The member states did not seem to intend to transfer powers to the Union in this particular field and as a result extend its competences.

The situation is different when it comes to the accession of EU to the Convention. A possible accession may affect both the relations of the Union with its member states under the ECHR law and those of the Union with the Convention itself. Therefore a more general term was used in the formulation of par. 2. The word "affect" is interpreted in a more balanced way; neither restrict, nor extend EU competences.

An issue that should be addressed first is what accession may change from a legal point of view. In terms of legal consequences, EU will become a party to the ECHR and submit its sui generis therein, despite the participation of all its member states to the Convention. The jurisdiction of the Strasbourg Court extends to all matters concerning the interpretation and application of the Convention and its Protocols; in other words it indicates revision of domestic legislation in cases of human rights violations. Translated in terms of EU's accession, it involves revision of the EU legislation and acts of its institutions. However, on the ECJ side, there is risk that this eventuality would not be appreciated because of the ECJ's exclusive jurisdiction on the interpretation and the application of Union law.

It is commonsense that the accession of EU to the Convention will bring an institutional novelty from the viewpoint that an international organization will for the first time accede. In order to be able to control possible aberrations, the EU lawmakers punctuated the concept of the special characteristics of the Union.

A notable observation is the absence of an explanation of what the special characteristics of the Union or what they consist of. One may think that are related with the organization of the Union as described in the treaties, thus the powers of its institutions as vested therein. The EU has been developed to an autonomous legal order however based on the principle of transferred powers by the member states. This contains the source of the Union competences, fields where the Union is entitled to legislate. Furthermore, on the ground of legal autonomy, the widely accepted principles of direct effect and supremacy contribute to the special nature of EU legal order. The way those principles have been formulated confirm the nature of Union as a branch of international law with some unusual, quasi-federal, blossoms (de Witte, 1999). 
Another concept of EU special characteristics could be tied up with its system of judicial protection. In particular, EU accession to the ECHR must not jeopardize the interpretative authority of the ECJ regarding Union law. To maintain uniformity in the application of European Union law and to guarantee the necessary coherence of the Union's system of judicial protection, it is therefore for the Court of Justice alone, in an appropriate case, to declare an act of the Union invalid (ECJ Case C-314/85 Foto Frost).

The Union's special institutional structure as a supranational organization is reflected to its horizontal impact. Geographically the EU covers 27 out of the 47 ECHR members that represent different legal systems and a population of over 500 million citizens, almost 5 times more than the most populated ECHR member, Russia. Therefore, the Union shall have a special treatment under the legal umbrella of the Convention on the ground of its special status as it will be set out below.

A core element that describes EU in internal and external actions is that of competences. Article 3 TFEU provides the Union with exclusive competences in some domains wherein only the Union has jurisdiction, thus exclusive competences comprise the peak of EU legal autonomy. The catalogue of article 3 is restrained in the fields of the custom union, the establishing of the competition rules necessary for the functioning of the internal market, monetary policy for the Member States whose currency is the euro, the conservation of marine biological resources under the common fisheries policy and common commercial policy.

Beyond dispute, even in those strict EU fields of policy the protection of human rights shall be ensured. However, the authority to judge upon EU law matters is the ECJ; the ECJ will remain the sole Supreme Court adjudicating on issues relating to EU law and the validity of the Union's acts. Although in the past the ECJ had modified its position after the development of ECtHR case law in issues related to certain aspects of the right of privacy (ECJ Case C-88/99 Roquette), the ECtHR will not acquire the status of a hierarchically superior court; no decision or judgement of the Strasbourg Court adopting a different interpretation in human rights will certainly oblige the Union to change its legislation especially in core issues like, for example, the common commercial policy or the competition rules.

The purpose of this approach is the protection of the EU autonomous legal order that includes its own principles. Since its establishment the Union has been trying to fulfill aims of economic nature by following a market oriented path and subsequently legislating accordingly. Although the ECJ in recent cases (ECJ Case C-112/00 Schmidberger; ECJ Case C-36/02 Omega) ruled in favour of traditional rights over economic norms, the tendency has always been that fundamental rights are not absolute and may be restricted under certain circumstances (ECJ Case C-62/90 Commission vs. Germany; ECJ Case C-84/95 Bosphorus). The Union does not give the impression of willing to disfeature its special characteristics, nor to reform its economic integration purposes and hence to forfeit its exclusive fields of action to a mere human rights external reviewer.

Nevertheless EU shall respect fundamental rights of the Convention. As has been dictated by many ECJ decisions, ECHR is of special significance (ECJ Case C-4/73 Nold; ECJ Case C-299/95 Kremzow). The protection of fundamental rights in Union is inspired by the concept that is given in specific rights included to the Convention which sets the minimum standards to provide European framework for protection of human rights (Lawson and Schermers, 1999). From this point of view, the Strasbourg Court acquires a subsidiary role in externally reviewing compliance with the Convention; the guarantee that the rights and freedoms set forth therein lies upon the authorities of the members as major actors in human rights protection (also confirmed by the High Level Conference on the Future of the European Court of Human Rights, 2010).

In addition, competences of the Union are related to human rights protection policy in a more direct way both in internal and external level. In the first category one may include article 19 TFEU that provides the Council with power to take actions in combating discrimination. The Union may also legislate in issues regarding equality among men and women at work (article 153, par. 1, issue i TFEU in conjunction with article 157 TFEU) and maybe the most significantly the shared competence that the Union enjoys in the ex-third pillar (article 4, par. 2, issue $\mathrm{j}$ TFEU). Another direct internal fundamental rights competence is the one of article $7 \mathrm{TEU}$. According to this provision, the Union is bestowed the power to monitor compliance of the member states with fundamental rights and apply sanctions in cases of serious and persistent breaches. In external level, the fundamental rights policy of the Union is guided by article 21 TEU which states among others that the Union shall define and pursue common policies and actions in all fields of international relations, in order to consolidate democracy, the rule of law and human rights. In practice the EU had already included human rights references in its international agreements under the name of "human rights clauses" (Brandtner \& Rosas, 1998).

There is no reason why the Union should not follow the interpretation of the Convention when exercising its human rights policy. By obtaining a catalogue of fundamental rights of its own, the Union codified and specified 
the general values of article 2 TEU (and subsequently of article 21 TEU) into human rights that express democracy and the rule of law. The EU Charter that embodies those values dictates in article 53 that the meaning and scope of the rights of the Charter that correspond to ECHR shall be the same as those laid down by the said Convention. Therefore the values of the Union are substantially incorporated to the Convention that in any case enjoys the reputation of being the most important instrument of fundamental rights in Europe.

Conversely, the Union might obtain more powers in human rights issues after the accession to ECHR. From the early period the accession debate included the strengthening of the Union and its institutions regarding human rights protection, a prospect that could empower the Union's position in that particular field in Europe. Under those circumstances, the role of the ECHR would be enervated (Chalmers, Davies \& Monti, 2010).

This may be in line with article 6, par. 3 TEU. This provision states that: "fundamental rights, as guaranteed by the European Convention for the Protection of Human Rights and Fundamental Freedoms and as they result from the constitutional traditions common to the Member States, shall constitute general principles of the Union's law".

The general approach that demonstrates the importance of human rights within the EU legal system was kept in the post-Lisbon era. It clearly illustrates the commitment of the Union in protecting fundamental rights. On the other hand, one may say that it keeps providing the Court with the power to adjudicate based on ECHR rights despite the existence of an EU bill of rights. This may lead to a constructive role of the ECJ that could create rights out of their formal EU basis, the Charter, based on principles of the Convention (de la Rochere, 2004). Consequently, the power that the ECJ kept may increase its importance and grant a central role in human rights issues to the Court.

This indirect empowerment of EU would not find its member states consistent. As directly stated in article 3, par. 6 , the Union is based on the principle of conferred competences. Should the member states determine to transfer powers regarding fundamental rights protection to the Union, they could follow a different technical path via a treaty amendment and subsequent inclusion of a relevant provision. This is also the reason of the clarification clause of article 6, par. 1 regarding the EU Charter and the Union competences.

Moreover, all EU member states are already signatories of the Convention under special characteristics related to reservations made according to article 57 ECHR. Reservations apply where a state is unhappy about particular provisions, it may, in certain circumstances, wish to refuse to accept or be bound by such provisions, while consenting to the rest of the agreement (Shaw, 2008). From this perspective, the member states of the Convention intend to adapt, up to a certain extent, the legal instrument to their specific political distinctiveness so that the application of the Convention within their respective national legal orders would be effortless.

The reservations generally indicate the exercise of powers in human rights by the member states. The theoretical possibility that the reservations of the EU member states within the ECHR would have been abrogated with the EU accession would have implied an indirect transfer of powers to the Union. The possibility of raising the reservations on behalf of the member states as an expression of sovereignty still exists; thus the revocation via a Union act (accession to ECHR) would displace the member states from determining their respective policies.

The reasons described led to the formulation of article 6, par. 2 and article 2 Protocol 8 in such a way that clarifies the position of all actors involved in the accession. Under the hierarchical distinction made by Polakiewicz (Polakiewicz, 2001), the ECHR does not appear to have a clear status within the EU legal order. A basic concern of the Union is evidently to guarantee a special status in the ECHR based on its institutional characteristics. Theoretically, even under those circumstances, this would not be problematic: the Union institutions shall respect the EU Charter of Fundamental Rights which provides with protection of at least at the same level with the Convention. Therefore, the ECHR shall be seen as a complementary, not an alternative instrument that provides of an additional safeguard for human rights protection (Pernice and Kanitz, 2004; Groussot and Pech, 2010). In practice, an institutional balance of the two legal orders shall be kept for the proper function of accession. The specific Union features must be respected; nevertheless this should in no occasion lead to institutional excesses.

For the achievement of institutional balance, the development of the relations of the two highest courts in their respective legal orders is essential. Recently, in an attempt to contribute to the accession process, the ECJ favored of the enactment of a specific mechanism for ensuring that the question of the validity of a Union act can be brought effectively before the Court of Justice before the ECtHR rules on the compatibility of that act with the Convention (Court of Justice of the European Union, 2010; European Court of Human Rights, 2011). In that sense the Union's judicial protection system, which consists of its special characteristics, would be sufficiently preserved.

An example of highest importance could be a claim of violation of the Convention rooted in the European Union's primary law, i.e. the treaties. Article 3, Protocol 8 of the Lisbon Treaty gives an initiative by stating that: 
"nothing in the agreement referred to in Article 1 (accession agreement) shall affect Article 344 of the Treaty on the Functioning of the European Union".

Article 344 TFEU practically forbids member states to submit a dispute concerning the interpretation or application of the EU primary law to any method of settlement other than those provided for in the treaties; it confirms that the sole and indisputable interpreter of the EU treaties is the ECJ as derived from many provisions therein (e.g. article 19 TEU, article 267 TFEU, etc.).

The logical outcome based on the above would be that the EU primary law should be excluded from the ECtHR scrutiny mechanism. In the relevant example the introduction of a mechanism that allows the Strasbourg Court to refer the case to the ECJ would prevent possible disputes. This idea is in line with the concept of Union's special characteristics; decisions of the ECJ regarding EU law affect 27 countries while a possible application of another method of settlement may impinge on policies that have been settled for years and under difficult circumstances. This could be used as a "backdoor" to weaken the process of European integration.

On the other hand, the same special mechanism could be used for an interpretation request of the Convention to the ECtHR on behalf of the ECJ. The main advantage of the process is that the ECJ would be in position to have an authoritative interpretation of the Convention to ground on for further development. Such a mechanism is tightly connected to the nature of the Strasbourg Court as delivering constitutional justice in the sense that the ECtHR will provide the ECJ and subsequently all EU member states (even non-EU member states) with an original interpretation of the conventional human rights.

Moreover, the establishment of an interpretative process would assist in avoiding divergences and hence promote cohesion among the case-law of the two courts. Total coincidence of views among the two courts would be an idealistic but rather impossible result. As a minimum, the interpretative mechanism provides the ECJ with a concrete starting point that assist a traditionally non-human rights court to ground its decisions. This approach is also in line with article 53 of the EU Charter that dictates a common interpretation with the Convention where possible.

A major disagreement regards the further postponement in delivering justice. The workload of the Strasbourg Court is commonplace; a workload that increases year by year. At first sight, the insertion of an interpretation reference mechanism seems like delaying cases even more. Giving a second thought, the ECtHR will be in a position to rule upon its actual field of specialization, human rights, in a way of delivering guiding principles rather than solving a particular problem. This process has dual benefits; the position of ECtHR as a constitutional court is re-defined (and confirmed) while its guiding principles lead to the avoidance of future time consuming relevant cases. Under those terms, the time issue will turn to be a positive aspect for the ECtHR applicant.

It is of highest significance to understand that the ECJ is not a supreme national court and shall not be confronted as one. Under the principle of supremacy the case law of ECJ (as European law) overcomes national law; plus from a horizontal perspective it influences 500 million people from different legal systems. Therefore the establishment of an interpretation request mechanism should not be regarded as a privilege granted to EU but rather than a further step towards the completion of European public order.

\section{Relations of the Union with the ECHR Member States under the Convention}

As the Strasbourg Court has ruled in its case law (App. No. 45036/98, Bosphorus), in fields of state actions in compliance with EU law obligations, the responsibility of the EU member states exists only if the Union does not protect fundamental rights at least at a level equal to the Convention, subsequently the EU member states are presumed not to have departed from the requirements of the Convention if the EU passes the test of "equivalent protection". By applying this principle, the ECtHR received much of criticism in the outcome of the Bosphorus case. One point was raised with regard to the level of scrutiny of the ECtHR towards EU member states in relation to that applied to non-EU member states. By transferring powers to the Union, the member states are substantially exempted, to some extent, from scrutiny to which non-EU members of the Convention are exposed, concerning the same state action (Besselink, 2009).

Inevitably, the situation will change after the EU accession to ECHR (for the opposite opinion Besselink, 2009). The rationale of the Strasbourg Court in all cases involving EU law, which led to the establishment of special principles in its judgements, was simply the fact that as EU was not a part of the Convention; the ECtHR had no direct competence in adjudicating upon EU legal acts regarding their compliance with human rights. The very reason why all cases were not declined inadmissible for jurisdictional reasons dissembled, on one hand, the will of the Strasbourg Court to take them into account, on the other hand, an action of a member state, which results admissibility under article 1 ECHR, was involved. 
Under the accession to ECHR there will be no justified reason for the continuation of the same attitude towards EU on behalf of the Strasbourg Court. By acceding to the Convention, the European Union will have agreed to have its legal system measured by the human rights standards of the ECHR. More importantly, the Union will have the rights to participate in proceedings before the ECtHR when EU law is at stake; it will no longer be the case that the member states have to act as sole respondents in lieu of the European Union (Lock, 2010). Therefore, there will no longer be a need for them to be privileged in cases currently covered by the presumption.

\subsection{The Union and Its Member States}

The first question regarding the judicial relations among the Union itself and the EU member states is with reference to responsibility. Statistically, most cases are brought to the ECtHR by individual applicants under article 34 ECHR. Protocol 8 of the Lisbon Treaty has already approached the issue. In article 1 it is stated that the mechanisms necessary to ensure that proceedings are correctly addressed to member states and/or the Union shall be elucidated in the accession agreement. Therefore the possibilities of misinterpretation will be reduced.

The issue of correct respondent is vital when EU law is at stake. Apparently, the Union would not be pleased about being in a position to defend itself for human rights violations that the member states have committed. One could propose that the criterion for distinguishing the correct respondent already exists in the treaties; the separation of competences. Part one, title I TFEU is dedicated to classification of competences. Hence, a possible solution would be to have the Union as responsible for its exclusive competences (also in cases of action under the subsidiary competences status) and both the Union and the respective member states in cases involved shared competences.

This solution should not be acceptable for two main reasons. Firstly, from a technical point of view, this distinction will directly transfer the power to the Strasbourg Court to interpret the treaties when defining responsibility. When a case finds its way, the ECtHR will inevitably have to judge upon arguments regarding the correct respondent. However, the allocation of responsibility between the EU and the member states falls under the exclusive jurisdiction of the ECJ; an issue that has already been specifically addressed in Opinion 1/91. Hence, the method of distinguishing responsibility before the ECtHR on the ground of EU internal division of competences will not be extremely effective.

The second reason is more substantial. Under the internal division of competences, it is highly probable that the Union will be solely responsible for human rights violations when legislating in issues of exclusive competence, for example in the field of common commercial policy. Nevertheless, a violation deriving from an EU piece of legislation is not existent in all cases. For cases where the member states enjoy discretion up to a certain extent when implementing EU law (e.g. directives), it is highly probable that the violation can be caused by the national measures. The member state may have exercised its discretion in a way, which violated the Convention and in such cases, it would be appropriate to hold the Member State responsible (Lock, 2011). Therefore the EU internal division of competences will turn to be a "shield" for the member states of the Union.

Deriving from the above mentioned, the solution regarding the distinction of responsibility between the EU and the EU member states can be found in the notion of discretion. The member states have no discretion when implementing EU primary law or EU regulations. Hence, it would be unfair for them to stand solely responsible for just fulfilling their obligations under EU law (for example in the ECtHR case App. No. 24833/94, Matthews vs. UK). Although, it is clear that the human rights violations substantially originate from EU law in such cases, the violation creates effects in the real world via an act of a member state. This became quite clear in Bosphorus where the ECtHR asserted that the case fell into the jurisdiction of Ireland within the scope of article 1 ECHR since the act that cause the violation was committed by Irish authorities. Under this perspective, the member states will always be in a defending position before the ECtHR, a fact that may lead to unfair results especially when a particular member state had initially disagreed during the legislative process for the adoption of the regulation.

On the contrary, the level of discretion that the member states enjoy when implementing EU directives is very high. A directive shall only be binding as to the result to be achieved, but leaves the member states free to legislate upon the form and methods. In that sense the acknowledgement of violation's root is more complicated; does it derive from the form and methods that a particular member state chose or does it exist in the very essence of the EU act so the member states could not avoid it?

In order for confusions to be avoided, where there might be any doubt about the way in which responsibility is shared; an application may be brought simultaneously against the Union and the member state (see also European Parliament, 2010). Furthermore, for finding the correct responsible actor, a new mechanism may be initiated. In cases of an application directed against a member state, the EU may join as a co-respondent and vice versa. This 
mechanism will also enhance the idea of the EU legal autonomy as a special characteristic since the Union will be in position to defend its legal acts more efficiently. The decision of the enactment of this mechanism should lie upon either the EU or the member states, not attributed by the Strasbourg Court. Under the latter, the ECtHR might enter the very substance of the case and in some sense pre-judging it, by granting some sort of acquittal to the respondent, when inviting another actor to participate as co-respondent.

The establishment of the co-respondent mechanism will be much more effective than the existing third party intervention of article 36 ECHR. Taking into consideration that the judgement has no legal effects to the intervener, no obligation would arise for the third-party to comply with it. In contrast, the co-respondent participates as an equal litigant accepting all effects of the trial. Moreover, the co-respondent mechanism shall be binding upon both the EU and the member states when asked to enter a case, unlike the non obligatory third party intervention instrument, in order for responsibilities to be assessed more precisely.

According to the Convention, the ECtHR may only deal with the matter after all domestic remedies have been exhausted (article 35, par. 1). This provision contains a proof of the subsidiary role of the Strasbourg Court. A crucial matter is the exhaustion of domestic remedies regarding EU law. In the cases involving an act of a member state, the respective domestic judicial review mechanism shall be used up to the last possible level of appeal. However, as long as EU law is somehow involved, this will not be enough under the purpose of article 35, par. 1 ECHR. As the EU as an autonomous legal order has its own system of jurisprudence; the EU courts shall also be incorporated in the concept of "domestic remedies". An opposite argument would contradict the very idea of accession under the view that the ECtHR should not examine EU law cases if the ECJ has already decided as another international investigation or settlement in the sense of article 35, par. 2, point b ECHR. The ECJ has also declared that where an act of the Union is challenged, it is a court of the Union before which proceedings can be brought in order to carry out an internal review before the external review (of the Strasbourg Court) takes place. Thus, the major concern of the ECJ is not its classification as an international court, but rather not to be dispensed when EU law is at issue.

The process that most effectively connects the national and European legal orders in terms of judicial review where individual are involved is the preliminary ruling. As stated in article $267 \mathrm{TFEU}$, for the ECJ interpretation of EU acts, the preliminary ruling is optional for regular national courts but obligatory for supreme national courts where no other national remedies are provided. The question is now whether the preliminary ruling process satisfies the domestic remedies concept of the Convention. The reason that the Convention process was established in such a way counts on the role of the Strasbourg Court as a subsidiary Court. After all domestic judiciary has ruled upon a case the ECtHR comes to express a more specialized opinion regarding human rights. Thus, all courts need to have spoken about the acts of the legal order they represent before a case reaches the ECtHR.

Under the preliminary ruling rise, the ECJ has the opportunity to give a definite ruling. An example could definitely be the case of Bosphorus where the Irish court used the preliminary ruling so that the ECJ had the opportunity to review the regulation as to its conformity with the European Union's fundamental rights before the case was brought to the ECtHR. The problem that may rise pertains to the situation where the national courts do not make a preliminary ruling reference to the ECJ when assuming that no duty to make such a reference exists. Furthermore, in strengthening the argument, the ECJ itself has stated that a national court even of last resort need not make a reference where it has established that the question raised is irrelevant or that the Community provision in question has already been interpreted by the Court or that the correct application of Community law is so obvious as to leave no scope for any reasonable doubt (ECJ Case C-283/81 CILFIT). Under those circumstances, the ECJ would not be in position to adjudicate before the Strasbourg Court.

For that reason a special reference mechanism can be used for avoiding institutional imbalances. Under the accession agreement, the EU legal order will further integrate with that of the Convention for receiving external review for its legal acts regarding compliance with human rights from a specialized court, as the Strasbourg Court is. In the judicial protection system of the Union that consists of one of its characteristics, the ECJ has the competence to rule upon issues with reference to EU legal acts. In cases that the preliminary ruling process of article 267 TFEU will not be followed, the Court will be substantially detoured. This parameter could be problematic since it leads to effects on the powers of the Union's institutions unlike the statement of Protocol 8 of the Lisbon Treaty. On the contrary, this special reference mechanism will give to the ECJ the opportunity to adjudicate before the Strasbourg Court so that the latter will take into account the ruling of the former as the Court representing the European legal order.

Regarding applications addressed against an EU legal act directly, the respective remedies should be exhausted. The concept of the Convention lies upon the idea of substantial domestic remedies in terms of effectiveness, not 
remedies that would in principle lead to inadmissibility. The individual complains procedure within the Union's legal system can be found in article 263, par. 4 TFEU. Under the Lisbon Treaty the concept of acts that can be challenged by individual became broader than before (Balthasar, 2010; Chalmers et al., 2010). This newly established provision, grants individuals with the opportunity to challenge EU acts that are addressed to them or which are of direct and individual concern to them and against regulatory acts which are of direct concern to them and do not entail implementing measures. Nevertheless, the term "regulatory act" is not very clear; in brief, this contains Regulations and Decisions of general application (on the concept of "regulatory act" Dashwood and Johnson, 2004; Dougan, 2008). Plus, article 265 TFEU covers individual in situations where the EU legal bodies have failed to act.

Both legal remedies shall be processed under the notation of article 256 TFEU. In line with that provision, the General Court is competent at first instance to deal with issues with reference to (among others) articles 263 and 265 TFEU. An appeal is possible to the ECJ which adjudicates only on points of law. Consequently, the remedies provided by the Lisbon Treaty could be regarded effective under the scope of ECHR.

As far as the individual applications are concerned, a matter of highest importance rises with reference to article 27 ECHR. Under this provision the single judge process is introduced in the system of the Convention. A single judge may either declare an individual's application inadmissible or to forward it for further examination. The decision of the judge is final. The purpose of the provision is to reduce the workload of the Strasbourg Court by rejecting plainly inadmissible applications. As long as it has been already agreed that a judge elected in respect of the Union will be a member of the ECtHR (Council of Europe, 2010a); details as to when the EU judge serves as single judge shall be clarified. The basic idea is that the judge shall not examine any applications against the state in respect of which he or she was elected (Council of Europe, 2010b). Hence, a first observation is that the EU judge should not sit as a single judge in applications against EU.

Taking into account that the European citizenship is substantially related to that of the EU member states, inevitably the EU judge will possess a citizenship of one of them. The issue is whether that judge will be able to adjudicate applications against the member state of his origin or even against another EU member state within that process. For example, if the judge elected on behalf of the Union is German, apparently he will not examine any applications against EU as a single judge on the basis of non examination of applications against the member in respect of which the judge was elected. But when applications against Germany are at stake, two possibilities could be seen; either examining it on the ground of EU autonomy and the impartiality and independency as principles discerning judges or not examining under the inevitable connection with his country of origin which may prevent him from being objective.

The examination by the EU judge of applications against his own country of origin should not be an acceptable solution. Under different circumstances, the principle dictating that the judge shall not examine any applications against the state in respect of which he or she was elected will be totally violated in its substance. The purpose of this principle was not simply to exclude examination of certain applications by certain judges on the basis of a typical citizenship relation between the citizen and the state but more to establish a strong substantial rule that enriches objectivity of a brand new procedure of the Strasbourg Court.

In that sense, objectivity is mostly achieved by excluding the EU judge from examining applications against his own state of origin. This is implied from the rather unique perception of EU citizenship. Citizenship of the Union could definitely be incorporated to the notion of special characteristics that shall not be affected from accession. This idea of special characteristics must not be solely interpreted from the perspective of Union's principles, but also from those of the ECHR in order for the institutional balance and thus integration of the two legal orders to be achieved. Therefore, an exception of the EU judge shall be forwarded regarding the applications that he has no competence to rule upon under the single judge procedure; applications against his country of origin.

Regarding the possibility of examining applications against another EU member state, the situation is rather explicit. Continuing the example described above, an EU elected judge to the ECtHR of German origin could examine a case directed against another member state e.g. Greece. The reason of lack of objectivity cannot be extended in such cases where the strong connection of citizenship between the state and the citizen does not exist. The idea that the EU is a Union of states should not be subject to such a broad interpretation that identifies the Union with its states. Therefore, the principle of legal autonomy of the Union must prevail so that the EU judge shall not been exempted from examining cases against other member states.

A more complex issue arises with reference to inter-state cases. Aside from individual complaints the Convention also provides for complaints brought by state parties under article 33 ECHR. The question is whether after accession of the Union inter-state complaints should be excluded as far as the member states and 
the Union are concerned. This issue creeps a deeper conflict of exclusive jurisdiction between the ECJ and the ECtHR.

On one hand, it is recalled that EU member states are prohibited from submitting disputes to any other method of settlement other than those provided for in the treaties (article 344 TFEU); a process that should be strictly protected from any misinterpretation resulting from accession. Article 7 TEU includes a specific procedure in cases regarding serious breaches of EU values by a member state which eventually embrace human rights. In addition, the position of the European Parliament contributes to the argumentation by stating that the member states should undertake, at the time of accession to the ECHR, with respect to one another and in their mutual relations with the Union, not to bring interstate applications concerning an alleged failure of compliance pursuant to article 33 of the ECHR when the act or omission in dispute falls within the scope of Union law. For the purpose of those cases, article 259, par. 1 TFEU provides the member state with the opportunity to bring a case before the ECJ regarding non compliance of another member state with the treaties; under article 263, par. 2 TFEU the ECJ may deal with challenges against legal acts of EU institutions while article 265, par. 1 TFEU give the right to open cases for failure to act.

Politically speaking, the possibility of including inter-state cases among EU member states and EU before the ECtHR could be abused. Since the early 90's, euroscepticism has been increased to a quite important ideology within the European political debate (Harmsen \& Spiering, 2010). Recent example of expression of euroscepticism regarding European integration in human rights may be seen in the opt-out protocol (Protocol 30 of the Lisbon Treaty) of the EU Charter of Fundamental Rights signed by the UK and Poland. From this standpoint, eurosceptics in governance of certain member states can persistently challenge EU before a specialized human rights court like the Strasbourg Court for possibly getting a positive ruling which may be used for further opposition to European integration.

On the other hand, the exclusive jurisdiction of the Strasbourg Court derives from article 55 ECHR. The provision prohibits the High Contracting Parties from availing themselves of treaties, conventions or declarations in force between them for the purpose of submitting a dispute arising out of the interpretation or application of the Convention to a means of settlement other than those provided for in the Convention. Therefore, it mostly seems that the ECHR parties have contracted out of the right to bring cases before another type of jurisdiction regarding issues that fall under the Convention (Tams, 2005; a different view is seen in Shany, 2003).

As by accession the Union will become a High Contracting Party to the Convention, hence the legal position under ECHR law would be that the ECHR member states (including EU member states) are entitled to bring a case against EU. Any opposite opinion in the sense of excluding the possibility of an inter-state case between the EU and its member states leads to substantial elimination of the principle of collective enforcement which is fundamental in ECHR law. Nevertheless, article 55 ECHR itself provides the Convention members with the right to make exceptions under a special agreement. In practice, the parties may waive the ECtHR jurisdiction and seek for the opportunity to have the dispute decided by another forum; but this willingness shall be proven in an agreement. Thus this matter turns to be internal between the EU and its member states. They would have to conclude a special agreement explicitly referring to the ECHR stating that the Convention will be interpreted by the ECJ in cases between the member states or between a member state and the EU. Therefore, the exclusive jurisdiction of the ECJ will be preserved and at the same time, will be in compliance with the requirements of the Convention (Lock, 2009).

\subsection{The Union and non-EU Member States of the Convention}

Accession to ECHR will not only vitally affect the relations among the EU and its member states, but raises potential judicial conflicts between the Union and the other mambers of the Convention under its legal system. As a High Contracting Party, the Union may have applications addressed against, before the ECtHR. The question here is how those judicial issues will be dealt from an ECHR standpoint.

For entering the Union, the candidate countries need to make progress on the ground of meeting the requirements for membership, most importantly the Copenhagen criteria one of which is the ability to take on the obligations of membership, including adherence to the aims of political, economic and monetary union and the administrative capacity to effectively apply and implement the acquis. The concept of the EU acquis includes the Union treaties as well as legislation and decisions adopted pursuant to the treaties and the case law of the ECJ (Delcourt, 2001; Kochenov, 2006). Therefore, countries negotiating their membership to the Union should implement to a large extent EU law.

The "European family" welcomes every European state that respects and promotes its values according to article 49 TEU; theoretically all members of the ECHR may apply for EU membership. Currently Turkey, Croatia, 
Iceland, the Former Yugoslav Republic of Macedonia (FYROM) and Montenegro, all ECHR members, are official candidates for acquiring EU membership, while Serbia and Albania have already applied. Hence, the countries mentioned need to follow the Union acquis a fact that may bring conflicts with the Union in terms of human rights violations.

The main problem addressed is that the candidate member states have no access to the ECJ. It is apparent that the relevant articles of TEU are directed to EU member states with no further reference to candidates; for example the preliminary ruling process of article 267 TEU is particularly focused on the national courts of full member states. In that sense there is no possibility for the candidate EU member states to reach the Court and as a result, the judicial institutions representing the legal order of EU will be skipped.

Under those circumstances, cases where EU law is at stake may reach the Strasbourg Court without the ECJ having the opportunity to rule upon. A possible solution could be the application of the two new mechanisms mentioned above; the reference to ECJ and the co-respondent mechanism. The idea of the Strasbourg Court referring to ECJ cases where non EU member states or EU are involved (at least not as both parties) may appear awkward at first glance. From one side, the ECJ will be empowered since it will be competent on adjudicating upon issues under a geographical expansion of its scope. On the other hand, the purpose to preserve the EU legal autonomy through adjudication of its courts in cases regarding EU law should prevail. Under those circumstances the ECJ will be in position to express its position as the Supreme Court at EU level before the Strasbourg Court will deal with the issue.

Furthermore, the reference process may be used as a tool for familiarizing the official candidate states with the EU judicial procedures. It is commonsense that the technical prerequisites for EU membership aim to formulate institutions of the candidate states in such a way that could be in a better position in applying and implementing EU law, the case law of the ECJ included. By acquiring the opportunity of participating in formal process before the ECJ, the candidate states will be identified with the main judicial body of the Union, in the most important issue, the protection of fundamental rights.

The model of co-respondent before the Strasbourg Court in cases targeting EU law shall be applied as well so that the Union will have the chance to participate more actively in proceedings. The background of the mechanism's idea lies upon perplexity regarding the correct actor responsible when EU member states actions are involved so that judicial grievances will be avoided. At the status of the candidacy for EU membership, states do implement EU legal acts so that the possibility of violating human rights through implementation does exist. Therefore, the situation of candidate states does not differ much in comparison with that of EU member states regarding responsibility. From this perspective, the co-respondent mechanism will upgrade the prospects in finding who is truly responsible.

\section{Conclusions}

The process of accession, a historic achievement for the protection of human rights in Europe, has already started. Finally a big step in further integration of Europe has been taken towards the completion of the European public order, inextricable part of which the protection of fundamental rights is. This contribution has attempted to give an overview of some of the most problematic and contentious issues of the accession by the EU to the ECHR. In order for the accession to be constructive, a harmonious and efficient interplay between the EU and the ECHR legal orders, including the national ones, is essential; this can be achieved under institutional balance. This view has been elaborated in official EU legal documents as well as opinions expressed by officers including, most importantly, the new article 6 TEU and the Protocol 8 of the Lisbon Treaty.

After the completion of accession all EU legal acts may be externally reviewed for conventional human rights compliance by the Strasbourg Court. This perspective sets the basis for the new relations between the two major Courts in Europe, the ECJ and the ECtHR. One way of establishing the new relations of the Courts is through the enactment of the two new mechanisms (reference and co-respondent) that distinguish the roles between them. Under the same principle of institutional balance, the Union shall be equally represented in bodies of the Convention, especially in the ECtHR taking into account its special characteristics as the first ECHR member that lacks the status of the state.

As the Convention will remain the minimum fundamental rights protection provider in Europe, the EU Charter of Fundamental Rights continues in further elaborating human rights based on that ground. Given the fact of the constitutional member states traditions that become apparent also in the Convention, with the addition of those of non-EU members, all "pillars" that compose fundamental rights protection in Europe will be enclosed. In that sense the idea (Besselink, 2007) of a Composite European Constitution -in the field of fundamental rights- turns to be closer than ever. 


\section{References}

Arnull, A. (1999). The European Union and its Court of Justice. Oxford: Oxford University Press.

Balthasar, S. (2010). Locus standi rules for challenges to regulatory acts by private applicants: the new art. 263(4) TFEU. European Law Review, 35, 542-550.

Besselink, L. (2007). A Composite European Constitution: Een Samengestelde Europese Constitutie. Groningen: Europa Law Pub.

Besselink, L. (2009). The European Union and the European Convention on Human Rights after the Lisbon Treaty: From Bosphorus Sovereign Immunity to Full Scrutiny? In A. Sabitha (Ed.), State Immunity: A Politico-Legal Study (pp. 179-196). Icfai: The Icfai University Press.

Brandtner, B., \& Rosas, A. (1998). Human Rights and the External Relations of the European Community: An Analysis of Doctrine and Practice. European Journal of International Law, 9, 468-490. http://dx.doi.org/10.1093/ejil/9.3.468

de Búrca, G. (2002). Convergence and Divergence in European Public Law: the case of human rights. In P. Beaumont, C. Lyons, \& N. Walker (Eds.), Convergence and Divergence in European Public Law (pp. 131-150). Portland: Hart Publishing.

Chalmers, D., Davies, G., \& Monti, G. (2010). European Union Law: Cases and Materials (2nd ed.). New York: Cambridge University Press. http://dx.doi.org/10.1017/CBO9780511841408

Commission of the European Communities. (1979). Accession of the Communities to the European Convention on Human Rights: Commission Memorandum. Luxemburg: Office for Official Publications of the European Communities. Retrieved from http://aei.pitt.edu/6356/4/6356.pdf

Commission of the European Communities. (2001). European Governance: A White Paper. Retrieved from http://eur-lex.europa.eu/LexUriServ/site/en/com/2001/com2001_0428en01.pdf

Council of Europe. (2010a). European Commission and Council of Europe kick off joint talks on EU's accession to the Convention Human Rights. Retrieved from http://www.coe.int/t/der/brusselsoffice/articles/restarticles/2010/jagland_reding_070710_EN.asp

Council of Europe. (2010b). Protocol 14: The reform of the European Court of Human Rights. Retrieved from http://www.echr.coe.int/NR/rdonlyres/57211BCC-C88A-43C6-B540-AF0642E81D2C/0/CPProtocole14EN .pdf

Court of Justice of the European Union. (2010). Discussion document on certain aspects of the accession of the European Union to the European Convention for the Protection of Human Rights and Fundamental Freedoms. Retrieved from http://curia.europa.eu/jcms/upload/docs/application/pdf/2010-05/convention_en.pdf

Craig, P. (2008). The Treaty of Lisbon, process, architecture and substance. European Law Review, 33, 137- 166.

Dashwood, A., \& Johnston, A. (2004). The institutions of the enlarged EU under the regime of the constitutional treaty. Common Market Law Review, 41, 1481-1518.

Davies, G. (2006). Subsidiarity: the wrong idea, in the wrong place, at the wrong time. Common Market Law Review, 43, pp. 63-84.

De Baere, G. (2008). Constitutional Principles of EU External Relations. Oxford: Oxford University Press. http://dx.doi.org/10.1093/acprof:oso/9780199546688.001.0001

Delcourt, C. (2001). The Acquis Communautaire: Has the Concept Had Its Day? Common Market Law Review, 38 , 829-870. http://dx.doi.org/10.1023/A:1011941728627

Dougan, M. (2007). The Treaty of Lisbon 2007: winning minds, not hearts. Common Market Law Review, 45, 617-703.

Eechkhout, P. (2004). External Relations of the European Union: Legal and Constitutional Foundations. New York: Oxford University Press.

European Parliament. (2010). Resolution on the institutional aspects of the accession of the European Union to the European Convention for the Protection of Human Rights and Fundamental Freedoms. Retrieved from http://www.europarl.europa.eu/sides/getDoc.do?pubRef=-//EP//TEXT+TA+P7-TA-2010-0184+0+DOC+X $\mathrm{ML}+\mathrm{V} 0 / / \mathrm{EN}$ 
European Court of Human Rights. (2011). Joint communication from Presidents Costa and Skouris. Retrieved from http://www.echr.coe.int/NR/rdonlyres/02164A4C-0B63-44C3-80C7-FC594EE16297/0/2011Commun ication_C EDHCJUE_EN.pdf

Evans, P., \& Silk, P. (2008). The Parliamentary Assembly: Practice and Procedure (10th ed.). Strasbourg: Council of Europe Publishing.

Frid, R. (1995). The Relations between the EC and International Organisations: Legal Theory and Practice. The Hague: Kluwer Law International.

Greer, S. (2008). What's Wrong with the European Convention on Human Rights? Human Rights Quarterly, 30, 680-702. http://dx.doi.org/10.1353/hrq.0.0014

Groussot, X., \& Pech, L. (2010). Fundamental Rights Protection in the European Union post Lisbon Treaty. Retrieved from http://www.robert-schuman.eu/doc/questions_europe/qe-173-en.pdf

Harmsen, R., \& Spiering, M. (2004). Euroscepticism and the Evolution of European Political Debate. In R. Harmsen, \& M. Spiering, Euroscepticism: Party Politics, National Identity and European Integration (pp. 13-36). New York: Rodopi B.V.

High Level Conference on the Future of the European Court of Human Rights. (2010). Interlaken Declaration. Retrieved from http://www.coe.int/t/dghl/cooperation/capacitybuilding/Source/interlaken_declaration_en.pdf

Kessedjian, C. (2007). Public Order in European Law. Erasmus Law Review, 1(1), 25-36.

Kochenov, D. (2006). Why the Promotion of the Acquis Is Not the Same as the Promotion of Democracy and What Can Be Done in Order to Also Promote Democracy Instead of Just Promoting the Acquis. Hanse Law Review, 2, 171-195.

Koopmans, T. (2003). Courts and Political Institutions: A Comparative View. New York: Cambridge University Press. http://dx.doi.org/10.1017/CBO9780511522253

de Lange, R. (2007). The European Public Order: Constitutional Principles and Fundamental Rights. Erasmus Law Review, 1(1), 3-24.

Lawson, R. A., \& Schermers, H. G. (1999). Leading Cases of the European Court of Human Rights (2nd ed.). Nijmegen: Ars Aequi Libri.

Leal-Arcas, R. (2006). EU Legal Personality in Foreign Policy? Boston University International Law Journal, 24, $165-212$.

Lock, T. (2009). The ECJ and the ECtHR: The Future Relationship between the Two European Courts. The Law and Practice of International Courts and Tribunals, 8, 375-398. http://dx.doi.org/10.1163/156918509X12537882648426

Lock, T. (2010). EU accession to ECHR: Implications for Judicial Review in Strasbourg. European Law Review, 6, 777-798.

Lock, T. (2011). Accession of the EU to the ECHR: Who Would Be Responsible in Strasbourg? In D. Ashiagbor, N. Countouris, \& I. Lianos (Eds.), The EU after the Treaty of Lisbon (pp. 109-136). Cambridge: Cambridge University Press.

McGoldrick, D. (1997). International Relations Law of the European Union. London: Longman.

Pernice, I., \& Kanitz, R. (2004). Fundamental Rights and Multilevel Constitutionalism in Europe. Retrieved from http://www.whi-berlin.de/documents/whi-paper0704.pdf

Piris, J. C. (2010). The Lisbon Treaty: A Legal and Political Analysis. New York: Cambridge University Press. http://dx.doi.org/10.1017/CBO9780511762529

Polakiewicz, J. (2001). The Status of the Convention in National Law. In R. Blackburn, \& J. Polakiewicz (Eds.), Fundamental Rights in Europe, the ECHR and its Member States, 1950-2000 (pp. 31-53). New York: Oxford University Press.

de la Rochere, J. D. (2004). The EU and the Individual: Fundamental Rights in the Draft Constitutional Treaty. Common Market Law Review, 41, 345-354.

Shany, Y. (2003). The Competing Jurisdiction of International Courts and Tribunals. Oxford: Oxford University Press. 
Shaw, M. N. (2008). International Law (6th ed.). New York: Cambridge University Press. http://dx.doi.org/10.1017/CBO9780511841637

Steering Committee for Human Rights. (2002). Study of Technical and Legal Issues of a Possible EC/EU Accession to the European Convention on Human Rights. Retrieved from http://www.coe.int/t/dghl/standardsetting/hrpolicy/Accession/Working_documents/Study_accession_UE_2 002_en.pdf

Steering Committee for Human Rights. (2010). Report: $70^{\text {th }}$ meeting, 15-18 June 2010. Retrieved from http://www.coe.int/t/dghl/standardsetting/cddh/Meeting\%20reports\%20committee/70th_en.pdf

Steering Committee for Human Rights. (2011). $6^{\text {th }}$ working meeting of the CDDH informal working group on the accession of the European Union to the European Convention on Human Rights (CDDH-UE) with the European Commission: Meeting Report. Retrieved from $\mathrm{http}: / /$ www.coe.int/t/dghl/standardsetting/hrpolicy/accession/Meeting_reports/CDDH-UE_2011_06_\%20R AP_en.pdf

Tams, C. J. (2005). Enforcing Obligations Erga Omnes in International Law. New York: Cambridge University Press. http://dx.doi.org/10.1017/CBO9780511494116

Tillman, N. R., \& Tillman, S. B. (2010). A Fragment on Shall and May. American Journal of Legal History, 50, 453-458.

Thomassen, J. (2002). Parties and Voters: The Feasibility of a European System of Political Representation. In B. Steunenberg, \& J. Thomassen (Eds.), The European Parliament: Moving towards Democracy in the EU (pp. 15-35). Maryland: Rowman and Littlefield Publishers.

Turner, C. (1999). Human Rights Protection in the European Community: Resolving Conflict and Overlap between the European Court of Justice and the European Court of Human Rights. European Public Law, 5, 453-470.

de Vel, G. (1995). The Committee of Ministers of the Council of Europe. Strasbourg: Council of Europe Press.

Verola, N. (2010). The new EU Foreign Policy under the Treaty of Lisbon. In F. Bindi (Ed.), The Foreign Policy of the European Union: Assessing Europe's Role in the World (pp. 41-50). Massachusetts: The Bookings Institution.

de Witte, B. (2011). Direct Effect, Primacy and the Nature of the Legal Order. In P. Craig, \& G. de Burca (Eds.), The Evolution of EU Law (pp. 323-362). Oxford: Oxford University Press.

\section{Case law}

Case C-26/62 Van Gend en Loos [1963] ECR 1.

Case C-4/73 Nold vs. Commission [1974] ECR 491.

Case C-283/81 CILFIT [1982] ECR 3415.

Case C-314/85 Foto Frost [1987] ECR 4199.

Case C-62/90 Commission vs. Germany [1992] ECR I-2575.

Case C-84/95 Bosphorus vs. Minister for Transport, Communications et al. [1996] ECR I-3953.

Case C-299/95 Kremzow vs. Austria [1997] ECR I-2629.

Case C-88/99 Roquette [2000] ECR I-10465.

Case C-112/00 Schmidberger vs. Austria [2003] ECR I-5659.

Case C-36/02 Omega [2004] ECR I-9609.

Opinion 1/75 [1975] ECR 1355.

Opinion 1/91 [1991] ECR I-6079.

Opinion 2/94 [1996] ECR I-1759.

Opinion 2/00 [2001] ECR I-9713.

App. No. 24833/94, Matthews vs. UK [1999].

App. No. 45036/98, Bosphorus Hava Yollari Turizm ve Ticaret Anonim Sirketi vs. Ireland [2006]. 